\title{
HASIL BELAJAR KEMAMPUANMENULIS TEKS DESKRIPSI BERBASIS LINGKUNGAN SISWA KELAS VII SMP NEGERI 2 KOTA BENGKULU TAHUN AJARAN 2016/2017
}

\author{
Gilang Permata Sari ${ }^{1}$, Syukri Hamzah ${ }^{2}$, dan Arono $^{3}$. \\ ${ }^{123}$ Program Studi Pendidikan Bahasa dan Sastra Indonesia \\ Jurusan Pendidikan Bahasa dan Seni \\ FKIP Universitas Bengkulu \\ gilangpermata457@yahoo.co.id
}

\begin{abstract}
Abstrak
Tujuan penelitian ini untuk mengetahui hasil belajar kemampuan menulis teks deskripsi berbasis lingkungan siswa kelas VII SMPN 2 Kota Bengkulu tahun ajaran 2016/2017. Metode yang digunakan Deskriptif dengan pendekatan kuantitatif. Populasi dalam penelitian ini adalah semua siswa kelas VII SMP Negeri 2 Kota Bengkulu yang berjumlah 245 orang siswa dari tujuh kelas. penelitian ini menggunakan teknik pengambilan sampel menggunakan teknik random sampling secara acak. Simple Random Sampling ialah sampel yang diambil dengan melakukan undian terhadap semua populasi. Jadi penentuan sampel dalam penelitian ini dilakukan saat peneliti mulai memasuki lapangan dan selama penelitian berlangsung. Sampel pada penelitian ini ialah seluruh siswa kelas VIIA berjumlah 34 siswa. Teknik pengumpulan data dilakukan dengan cara observasi dan tes menulis teksd deskripsi yang dilakukan oleh siswa. Analisis data yang digunakan dalam penelitian ini analisis data kuantitatif. Hasil penelitian ini menunjukkan bahwa hasil belajar kemampuan menulis teks deskripsi berbasis lingkungan siswa kelas VII SMPN 2 Kota Bengkulu berada pada frekuensi 62-74\% dengan nilai 73,94 kategori (cukup).
\end{abstract}

Kata kunci: Hasil Belajar, Kemampuan, Teks Deskripsi, Berbasis Lingkungan.

\begin{abstract}
The purpose of this study to determine the results of learning ability to write text description of environment-class students VII SMPN 2 Bengkulu City academic year 2016/2017. Descriptive method used with quantitative approach. The population in this study were all students of class VII SMP Negeri 2 Kota Bengkulu which amounted to 245 students from seven classes. This research uses sampling technique using random sampling technique randomly. Simple Random Sampling is a sample taken by drawing all the populations. So the determination of the sample in this study was done when the researchers started entering the field and during the study took place. The sample in this study is all students of class VIIA amounted to 34 students. Technique of data collecting done by observation and writing test of text and description done by student. Data analysis used in this study quantitative data analysis The results of this study indicate that the results of learning ability of writing text description of environment-class students VII SMPN 2 Bengkulu City is at the frequency of $62-74 \%$ with a value of 73.94 categories (enough).
\end{abstract}

Keywords: Learning Result, Abilities, Description Teks, Environment Based. 


\section{PENDAHULUAN}

setiap manusia adalah makhluk yang belajar, atau belajar dilakukan oleh semua makhluk hidup. Dalam belajar, seseorang dapat memperoleh keterampilan, kemampuan, keahlihan serta sikap sesuai dengan keinginan dan tujuan dari belajar. Sudjana (2005:5) menyatakan bahwa belajar sebagai suatu proses mengandung tiga unsur yang dapat dibedakan, yaitu tujuan instruksional, pengalaman belajar, dan hasil belajar. Kegiatan belajar dimaksudkan sebagai ranah menemukan informasi baru yang nantinya menjadi ladang memperoleh ilmu pengetahuan. Hasil belajar adalah salah satu faktor atau bagian terpenting di dalam kegiatan belajar. Seseorang dikatakan belajar sesuatu apabila dalam dirinya telah telah terjadi perubahan. Menurut Ani (2002:34) hasil belajar merupakan perubahan perilaku yang diperoleh pembela setelah menjalani proses belajar. Proses pembelajaran pada dasarnya merupakan proses komunikasi dan interaksi antara peserta didik dengan pendidik yang diselenggarakan untuk mencapai tujuan belajar yang dibutuhkan. Oleh karena itu, baik proses maupun hasil belajar adalah rangkaian pembelajaran untuk mencapai tujuan pembelajaran yang diinginkan.

Pembelajaran bahasa Indonesia akan lebih menarik bila menggunakan lingkungan sebagai sumber belajar untuk teks yang akan ditulis. Dengan melakukan hal tersebut siswa mengetahui tentang lingkungan sekitar sekolah, bukan hanya itu siswa dapat melihat, merasakan, serta lebih menguasai materi pembelajaran melalui langkahlangkah pembelajaran. Menurut Harsiati (2016:20) terdapat beberapa langkah pembelajaran dengan menggunakan pendekatan saintifik yaitu mengamati, menanya, mengumpulkan informasi, mengasosiasi, dan, mengkomunikasikan.
Pembelajaran ini penting untuk diterapkan pada bidang pembelajaran bahasa Indonesia. Dengan ini siswa cepat menyerap informasi yang mudah di dapat dari lingkungan sebagai sumber belajar, sehingga siswa dengan mudah memahami isi materi pembelajaran. Kita tahu bahwa lingkungan sebagai sumber pembelajaran, sekolah hanya menyediakan ilmu dengan teori, tetapi bila kita terjun kelingkungan ilmu itu bisa digunakan dan dapat diperoleh lebih banyak lagi.

Penggunaan lingkungan yang tepat akan membantu mengatasi kesulitan pembelajaran dan memilih lingkungan sebagai alternatif yang tepat karena lingkungan akan memberikan pengalaman sendiri bagi pengetahuan peserta didik, bukan hanya itu jumlah sumber belajar yang tersedia di lingkungan banyak dan tidak terbatas. Selain itu, penelitian ini penting dilakukan karena siswa mendapatkan informasi dan belajar dari sekolah, tetapi sumber atau data bisa ia peroleh dilingkungan sekitar mereka, dengan demikian penulis ingin mengangkat permasalahanhasil belajar kemampuan menulis teks deskripsi berbasis lingkungan siswa SMP Negeri 2 Kota Bengkulu.

\section{METODE}

Penelitian ini menggunakan metode deskriptif Kuantitatif. Tujuan dari penelitian ini ialah mengungkap fakta, keadaan, fenomena, variabel dan keadaan yang terjadi saat penelitian sedang berjalan dengan gambaran yang apa adanya. Penelitian ini dirancang menggunakan metode deskriptif yang bertujuan untuk mendeskripsikan data dan fakta yang berkaitan dengan variabel yang diteliti, hasil penelitian ini berupa gambaran angka, bahwa Penelitian deskriptif adalah metode penelitian yang bertujuan untuk menggambarkan secara utuh dan mendalam tentang realitas sosial dan 
berbagai fenomena yang terjadi di masyarakat yang menjadi subjek penelitian sehingga tergambarkan ciri, karakter, sifat, dan model dari fenomena tersebut.

\section{HASIL DAN PEMABAHASAN}

Berdasarkan data yang diperoleh penulis, hasil penelitian ini dipaparkan dalam bentuk angka-angka tentang hasil belajar menulis teks deskripsi berbasis lingkungan sekolah siswa kelas VII SMPN 2 Kota Bengkulu. Data diperoleh berdasarkan hasil penelitian langsung dilapangan oleh penulis dibantu guru kelas VII SMPN 2 Kota Bengkulu, dengan KD 4.2 Menyajikan data, gagasan, kesan dalam bentuk teks deskripsi tentang objek (sekolah, tempat wisata, tempat bersejarah, dan/atau suasana pentas seni daerah) secara tulis dan lisan dengan memperhatikan struktur, kebahasaan baik secara lisan maupun tulis. Dalam menganalisis data hasil belajar kemampuan menulis teks deskripsi ini penulis dibantu oleh guru yang ikut terlibat langsung dalam kegiatan pembelajaran, sehingga penilaian terhadap teks yang dibuat siswa dilakukan oleh guru (P1) dan penulis (P2). Setelah menilai hasil belajar siswa berdasarkan aspek yang dinilai, perolehan nilai siswa ditotalkan dan dibagi dua sehingga diperolehlah N1 sebagai nilai akhir tiap subjek.

\section{Hasil Belajar Kemampuan Menulis Teks Deskripsi Berbasis Lingkungan Siswa Kelas VII SMPN 2 Kota Bengkulu}

Setelah dilaksanakan kegiatan belajar menulis teks deskripsi berbasis lingkungan di SMPN 2 Kota Bengkulu maka diperoleh hasil belajar kemampuan menulis siswa berada pada kategori cukup. Hasil perhitungan dari nilai maksimal 35 tersebut diperoleh nilai rata-rata sebesar 70.14 yang berarti berada lebih kecil dari modus yaitu 84, sedangkan nilai median 74.25 hampir mendekati nilai rata-rata. Standar deviasi diperoleh 14,13 ini berarti bahwa nilai yang diperoleh siswa terpencar, karena semakin tinggi nilai standar deviasi maka semakin tersebar pula nilai yang diperoleh oleh masing-masing siswa. Dengan melihat hal ini berarti nilai yang diperoleh siswa cenderung mendekati nilai rata-rata, dan median. Nilai 70.14 dan 74.25 berada pada rentang $62-74 \%$ pada kategori cukup. Jadi dapat dinyatakan bahwa hasil belajar kemampuan menulis teks deskripsi berbasis lingkungansiswa kelas VIISMPN 2 Kota Bengkulu berada pada kategori cukup.

Dari analisis data yang telah dilakukan dan gambaran hasil yang diperoleh bahwa siswa kelas VII SMPN 2 Kota Bengkulu kemampuan menulis teks deskripsi menggunakan lingkungan sebagai sumber belajar berada pada kategori cukup.tetapi secara keseluruhan tergambar bahwa lingkungan memberikan peran positif terhadap pemahaman siswa tentang materi teks deskripsi ini, sesuai dengan hakikatnya bahwa teks deskripsi adalah sebuah teks yang di dalamnya berisikan perincian atau melukiskan dan mengemukakan objek yang sedang dibicarakan (Tarigan,1996:52). Dengan demikian kita dapat mengetahui kemampuan siswa dalam mengungkapkan gagasan terhadap objek yang diamati berada pada kategori cukup. Penilaian terhadap hasil belajar kemampuan menulis siswa ini meliputi aspek isi yang dijabarkan, penyusunan kalimat sehingga menjadi paragraph yang utuh sesuai dengan struktur teks, pemilihan diksi atau pilihan kata yang cocok dan tepat dalam menerangkan objek yang diamati, serta penggunaan bahasa dan mekanik yang tepat. 
Penilaian Terhadap Aspek Isi Hasil Belajar Kemampuan Menulis Teks Deskripsi Berbasis Lingkungan Siswa Kelas VII SMPN 2 Kota Bengkulu

Dalam suatu karangan, hal yang paling penting bagi pembaca maupun penulis ialah isi dari tulisan itu sendiri, oleh karena itu dalam memproduksi suatu karya baik sastra maupun ilmiah isi memiliki peranan penting sebagai penyampai pesan. Menurut KBBI (2016) isi adalah sesuatu yang ada, apa yang tertulis di dalamnya (tentang buku, surat, dan sebagainya). Berdasarkan hasil analisis data yang telah dilakukan terhadap karangan siswa tentang hasil belajar menulis teks deskripsi siswa kelas VII SMPN 2 Kota Bengkulu, dari segi aspek isi pembelajaran menulis teks deskripsi siswa dalam kategori baik berada pada rentang skor $23,10 \%$.

\section{a. Penilaian Terhadap Aspek Struktur Hasil Belajar Kemampuan Menulis Teks Deskripsi Berbasis Lingkungan Siswa Kelas VII SMPN 2 Kota Bengkulu}

Berdasarkan data yang diperoleh maka penulis memaparkan penilaian dari aspek isi pada tabel di atas terlihat bahwa hasil perhitungan dari nilai maksimal 25 tersebut diperoleh nilai rata-rata sebesar 19,13 yang berarti nilai rata-rata siswa lebih kecil dari modus yaitu 25 , sedangkan nilai median 20 kecil dari nilai modus. Standar deviasi dari penilaian terhadap apek isi yaitu 5,25 ini berarti bahwa sebaran nilai yang diperoleh siswa berada jauh dari nilai rata-rata siswa, karena semakin tinggi nilai standar deviasi maka semakin tersebar pula nilai yang diperoleh oleh masing-masing siswa. Dengan melihat ini berarti nilai yang diperoleh siswa cenderung mendekati nilai median. Nilai 19,13 berada pada rentang 16-20 dengan kategori baik. Jadi dapat disimpulkan bahwa penilaian hasil belajar menulis teks deskripsi pada aspek organisasi berada pada kategori baik.

\section{b. Penilaian Terhadap Aspek Diksi Hasil Belajar Kemampuan Menulis Teks Deskripsi Berbasis Lingkungan Siswa Kelas VII SMPN 2 Kota Bengkulu}

Berdasarkan data yang diperoleh maka penulis memaparkan penilaian dari aspek diksipada tabel di atas terlihat bahwa hasil perhitungan dari nilai maksimal 15 tersebut diperoleh nilai rata-rata sebesar 10.67 yang berarti nilai rata-rata siswa lebih besar dari modus yaitu 9, sedangkan nilai median 10,25 besar dari nilai modus. Standar deviasi dari penilaian terhadap apek diksi yaitu 1,89 ini berarti bahwa sebaran nilai yang diperoleh siswa mendekati nilai rata-rata, karena semakin tinggi nilai standar deviasi maka semakin tersebar pula nilai yang diperoleh oleh masing-masing siswa. Dengan melihat ini berarti nilai yang diperoleh siswa cenderung mendekati nilai median. Nilai 10.67 berada pada rentang 10-12 dengan kategori baik.

\section{c. Penilaian Terhadap Aspek Penggunaan Bahasa Hasil Belajar Kemampuan Menulis Teks Deskripsi Berbasis Lingkungan Siswa Kelas VII SMPN 2 Kota Bengkulu}

Berdasarkan data yang diperoleh maka penulis memaparkan penilaian dari aspek penggunaan bahasa pada tabel di atas terlihat bahwa hasil perhitungan dari nilai maksimal 15 tersebut diperoleh nilai ratarata sebesar 10.35 yang berarti nilai rata-rata siswa lebih besar dari modus dan median yaitu 10, Standar deviasi dari penilaian terhadap apek isi yaitu 1,82 ini berarti bahwa sebaran nilai yang diperoleh siswa mendekati nilai rata-rata, karena semakin tinggi nilai standar deviasi maka nilai yang diperoleh oleh masing-masing siswa 
mendekati nilai rata-rata. Dengan melihat ini berarti nilai yang diperoleh siswa jauh dari nilai modus median. Nilai 10.38 berada pada rentang 10-12 dengan kategori baik. Jadi dapat disimpulkan bahwa penilaian hasil belajar menulis teks deskripsi pada aspek penggunaan bahasa berada pada kategori baik.

\section{d. Penilaian Terhadap Aspek Mekanik Hasil Belajar Kemampuan Menulis Teks Deskripsi Berbasis Lingkungan Siswa Kelas VII SMPN 2 Kota Bengkulu}

Berdasarkan data yang diperoleh maka penulis memaparkan penilaian dari aspek mekanikpada tabel di atas terlihat bahwa hasil perhitungan dari nilai maksimal 10 tersebut diperoleh nilai rata-rata sebesar 6.58 yang berarti nilai rata-rata siswa lebih besar dari modus yaitu 6 dan nilai mdian 6.75, Standar deviasi dari penilaian terhadap apek isi yaitu 1.04 ini berarti bahwa sebaran nilai yang diperoleh siswa mendekati nilai rata-rata, karena semakin tinggi nilai standar deviasi maka semakin tersebar pula nilai yang diperoleh oleh masing-masing siswa. Dengan melihat ini berarti nilai yang diperoleh siswa jauh dari nilai modus median. Nilai 6.58 berada pada rentang 5-6 dengan kategori cukup. Jadi dapat disimpulkan bahwa penilaian hasil belajar menulis teks deskripsi pada aspek mekanik berada pada kategori cukup.

\section{PENUTUP}

Kesimpulan

Berdasarkan hasil penelitian dan pembahasan, dapat disimpulkan bahwa hasil belajar kemampuanmenulis teks deskripsiberbasis lingkungan siswa kelas VII SMPNKota Bengkulu yaitu 70.14\% (cukup), hal ini dilihat sesuai dengan pengamatan terhadap hasil belajar kemampuan menulis teks deskripsi yang telah dilaksanakan sebelumnya, dan penilaian terhadap hasil kegiatan menulis teks deskripsi yang telah dilaksanakan siswa kelas VII SMPN 2 Kota Bengkulu.

\section{Saran}

1. Bagi guru Bahasa Indonesia SMA Negeri 1 Air Besi Kabupaten Bengkulu Utara bisa menggunakan media ini dalam pembelajaran yang sesuai untuk pembelajaran menulis

2. Bagi siswa, penelitian ini diharapkan dapat membuat siswa untuk lebih aktif dan dijadikan motivasi belajar menulis sehingga dapat meningkatkan keterampilan menulis selama disekolah.

\section{DAFTAR PUSTAKA}

Ani, Catrina dkk. 2002. Belajar dan Pembelajaran. Jakarta: PT. Rineka Cipta.

Tarigan, Henry Guntur. 2013. Menulis: Sebagai Suatu Keterampilan Berbahasa. Bandung: CV Angkasa.

Sudjana, Nana. 2005. Penilaian Hasil Proses Belajar Mengajar. Bandung: Tarsito.

Harsiati, Titik dkk. 2016. Bahasa Indonesia Edisi Revisi. Jakarta: Kementerian dan Kebudayaan. 